\title{
CODE CHOICE WITHIN INTERCULTURAL COMMUNICATION AMONG ETHNIC MINORITY IN BRUNEI
}

\author{
Fatimah Chuchu \\ Najib Noorashid \\ Universiti Brunei Darussalam \\ fatimah.chuchu@ubd.edu.bn; njb-on9@hotmail.com \\ Article received: 13 October 2014 \\ Final draft received: 30 June 2015
}

\begin{abstract}
The influences of globalisation and multilingualism have caused linguistic diversity and emergence of interesting and unique sociolinguistic phenomena, for instance, language contact in intercultural communication. As the study of intercultural communication has yet to be studied at large, this research takes the opportunity to embark on a descriptive study of code choice within intercultural communication, relating to the ethnic minorities in Brunei Darussalam. This investigation aims to identify these ethnics' preferable code choice within intercultural communication, and their needs and motivations practising those codes in a shared multilingual setting. Involving empirical investigation, this study was conducted to 60 native Brunei ethnic groups in Mukim Ukong, Tutong District. The research found code choice in multilingual settings and intercultural communications is a relatively complex sociolinguistic phenomenon, where speakers will employ different dialects or languages at an episode of communication, but still mutually understand by each other. To some extent, some speakers also accommodate their speech styles or languages to ease communication process between parties. The hegemony of globalisation, local vernacular, speakers' background and setting, among others, influence the selection of their everyday code choice.
\end{abstract}

Keywords: multiligualism, code choice, intercultural communication, language contact

The belief of 'a language for a people' might seem outdated in today's contemporary perspective of sociolinguistics. As Gal (2007) claimed, contrary to monolingualism, which had been seen as 'a natural human condition', recent research and findings by linguists and anthropological linguists have shown that multilingualism generates various global cultures and ideologies which are fundamental to language research. The influences of multilingualism and globalisation have raised linguistic diversity; furthermore, they have generated unique and interesting sociolinguistics phenomena; for instance, the language contact within intercultural communication.

Intercultural communication can be understood as a face-to-face interaction among people of different cultures (Jandt, 1998). Based upon languages in contact within inter-communication, Swann et al. (2004) suggested contact language normally emerges when two or more speech communities within a particular place practise different native languages and communicate with each other as a mean of socialising. Trudgill (2003) has stated that intercultural communication which involves two or more practices of intelligible languages or codes will normally cause complication during conversations. Nevertheless, for a certain period of time, 'intelligible' intercultural communication could become mutual, which to some extent could instigate language accommodation, or 'koinisation' (dialect levelling).

As "language choice is a fundamental characteristic of intercultural communication" (Tsuda, 1986: p. 69), current study agrees inter-communication is indeed closely related to the selection of a specific code. Code can be referred to as a neutral term of a language, dialect or even register. Fishman (1972) suggested that code choice is associated with the desire of a speaker practising a certain code within an episode of communication. Generally, every speaker has no constraint to choose his/her preferable code when conversing. Nevertheless, there are certain codes that are associated with particular contexts-of situation, topics, and speakers, among others. The speech communication and episodes in intercultural context normally exhibit interesting sociolinguistic phenomena, where they are expected to apply multilingual phenomena but mutually are understood by each other, even though they come from diverse cultural backgrounds and practise different languages.

In the past, the investigations on intercultural communication have been extensively undertaken within sociolinguistics study at the international level. For instance, the study of Gumperz(1982) investigated intercultural communication in the main airport's cafeteria in Great Britain, involving Indian and English speakers of different cultures. Although both speakers used the same code of English, the study had shown that intercultural communication could trigger certain complications, as both speakers have different cultural perception and understanding. Goebel (2002) who investigated a language choice of two neighbourhoods in Semarang, Central Java, found that the code choices of these people are rather complex, where dialect of ngoko Javanese was used to signal intimate relations among 
Javanese, while other local varieties of Indonesia were used to signal distant relationship (kromo). This finding has disapproved the local perception of Indonesian Malay to be the main code within any inter-ethnic communication within these areas. Shaleh (2010), through his study of intercultural communication between the Malays and Ibans that is based on bilingualism perspective within a local area of Badau, Indonesia, suggested as speakers are bilingual, the two speech communities are able to communicate with each other by their native languages. They could simply change the code based on their needs, without any complications.

This study takes the opportunity to explore the intercultural communication between two or more ethnic groups in a shared local community involving ethnic minorities in Brunei Darussalam (henceforth Brunei). This sociolinguistic investigation does not deliberately discuss the process of contact language, but aims to embark on the identification of code choice within intercultural communication, involving certain ethnic minorities, their needs and motivations practising such codes in a shared multilingual setting. Ethnic minority in Brunei refers to the "indigenous ethnics: of Bruneians. As for the current study, it focuses on the code choice among the minority group of Dusun ethnic, as they have intercommunication with other local ethnic groups within Mukim Ukong, Tutong District, in a daily basis. This study is undertaken to achieve the objectives of (i) identifying the code choice used by these ethnic groups in their daily communication; (ii) eliciting the needs and motivations for practising such codes; and simultaneously, (iii) identifying whether the different code choices through a communication episode as a part of multilingual phenomenon will cause complication or misunderstanding among the speakers.

the current study also believes that multilingual phenomena exist as speakers will practise 'mutually intelligible codes'. This means that they can speak multiple languages in a speech communication between participants. For instance, speaker A converses in Dusun to speaker B who practises Kedayan Malay, so speaker A will simultaneously be able to converse with speaker C who employs Brunei Malay. This should not affect their communication and comprehension as they are believed to be multilingual. Hence, an empirical study was conducted by implementing research methodologies, such as observation, survey distribution and interviews to probe into the phenomenon.

\section{Brunei as a multilingual country}

Brunei as a multilingual nation is known for its diversity of populations and cultures, which include those from the indigenous, permanent residents, and immigrants. According to the Constitution of Brunei of 1959, the Citizenship Status Law of 1961 section 4(1) (a), the recognised indigenous Bruneian people in Brunei Darussalam are those with Malay descent of seven ethnic groups, namely: Brunei, Kedayan, Murut, Dusun, Bisaya, Belait, and Tutong (The Government of Brunei,
1961). Chuchu (2009) claimed each of these ethnic groups has its own code and practises these languages or dialects. This finding is also confirmed by David, Cavallaro and Coluzzi (2009) who pointed out that only Dusun and Bisaya are considered as two dialects of the same language. However, the language of Brunei Malay is often used as a code for everyday communication, whether in intercultural communication, or informal situation. Based on previous research, it has been proven that Brunei-Malay continues to retain its force as the general lingua franca among the people of Brunei (Gunn, 1997).

David, Cavallaro, and Coluzzi (2009) claimed that Brunei is a very diverse country with linguistic heritage, like the rest of Borneo. Aside of the standard Malay which acts as the official language, and English with its instrumental value, there are other eleven languages spoken in Brunei: Brunei Malay, Kedayan, Tutong, Belait, Dusun, Bisaya, Murut (Lun Bawang), Iban, Penan, Mukah, alongside variations of Chinese language as Mandarin, Hakka, Hokkien, Cantonese, Hainan, Teochew, and Foochow. Variations of languages and dialects in Brunei are believed to have their prestige based upon their value and custom practices. Adiglossia study of sociolinguistics phenomena in Brunei by Chuchu and Poedjosoedarmo (1995) has shown that Bruneian language practice is strongly correlated to its triglossic situation, where: English language is having the highest prestige for its instrumental value for work and study; Brunei Malay as a local vernacular having a middle prestige and; the other ethnic languages and dialects are considered as having the lowest prestige. This research deliberately suggests that every speaker has their own liberty in choosing code-choices based on their needs and motivations.

Based on preliminary observation of local situation, the study of language contact and intercultural communication has been inadequately carried out in Brunei, particularly in reference to the ethnic minorities in Brunei. Karim (2005) has discussed how language contact happens, its culture and impacts on the intercultural linguistic system - Karim discussed the process of lexical accommodation and borrowing resulting from language contact, either phonologically, morphologically, syntactically, or semantically. More linguistic studies on the ethnic minority of Dusun in Brunei are usually executed based on discussion of its language structures and systems (Alas,1995; Karim, 2008; Fok, 2008; Halus, 2009), or a comparison of this language systems to the Malay language (Karim,2007), as well as studies based on historical linguistics (Alas, 2009).

\section{METHOD}

This investigation implemented three types of research methodologies. Observation was carried out with the residents in the Mukim Ukong during preliminary research. This was done in a more relax setting; thus communication among the focused community could be 
scrutinised subsequently. This also provides greater opportunity for researchers to acquire reliable speech data from the focused population. Episodes of communication among the speakers were recorded for further documentations, to prove the existence of linguistic entity and codes used between speakers

Survey was also used to elicit primary data, including populations' demographic data, speakers' behaviours and informants' experiences as well as their ideology-based on their belief, perception and motivation. A total of 60 questionnaires were distributed to local residents in Mukim Ukong, of which were returned. Interviews were done subsequently with several respondents to help researchers ascertain more indepth information. Interviews were done in BruneiMalay as it is understood by both parties. Respondents and informants were selected extensively from youngsters, youth, and senior citizens. Real names of informants used in current writing had been agreed by them. Secondary data related to the current study were also examined, through academic writings, research reports and conference papers as well as previous references available on the internet.

The study was conducted to 60 native speakers of

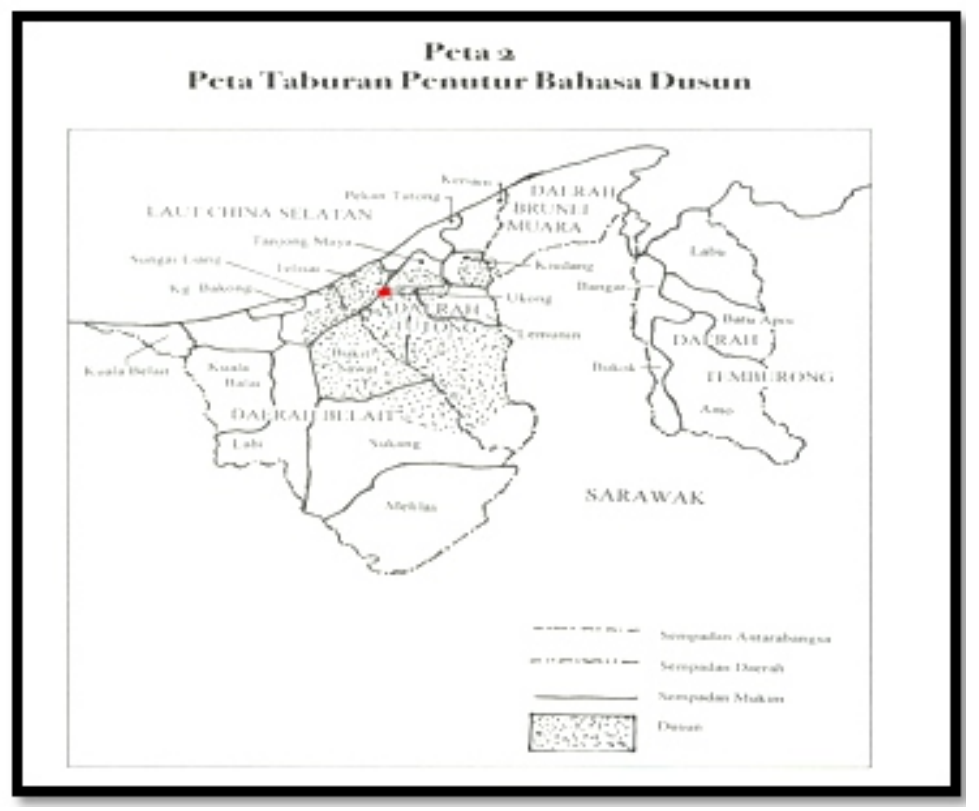

Figure 1, map of distribution of Dusun speakers in Brunei

(Karim, 2007: p. 19)

indigenous Bruneians within Mukim Ukong in Tutong District. With an area of 144.0 square kilometres, Mukim Ukong is populated by 2194 residents (as of the research was undertaken). Based on a statement by the Penghulu (a Malay term to refer to a headman of villages appointed by the government) of Mukim Ukong, Awg. Hj Omar Abdul Aziz (personal communication, 2013), the statistic numbers of ethnic residents in Mukim Ukong in
2007 was 2,051 as of 2013, with the majority of them are Dusun natives, seven are Bruneian-Malay, and 10 natives of Kedayan Malay, while 116 people are Chinese and 10 Ibans. This statistic includes all three villages of Kampong Bukit Tutong, Kampong Ukong and Kampong Long Mayan under the same Mukim Ukong. The existence of native Dusun community within this area had already been found by a previous study of Karim

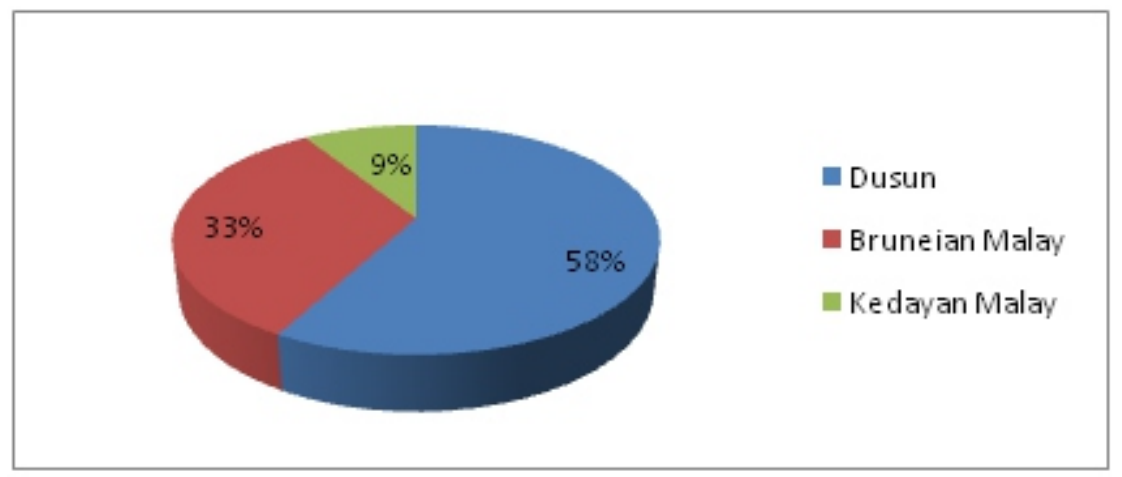

Diagram 1. Percentages of ethnicities involved in current study 


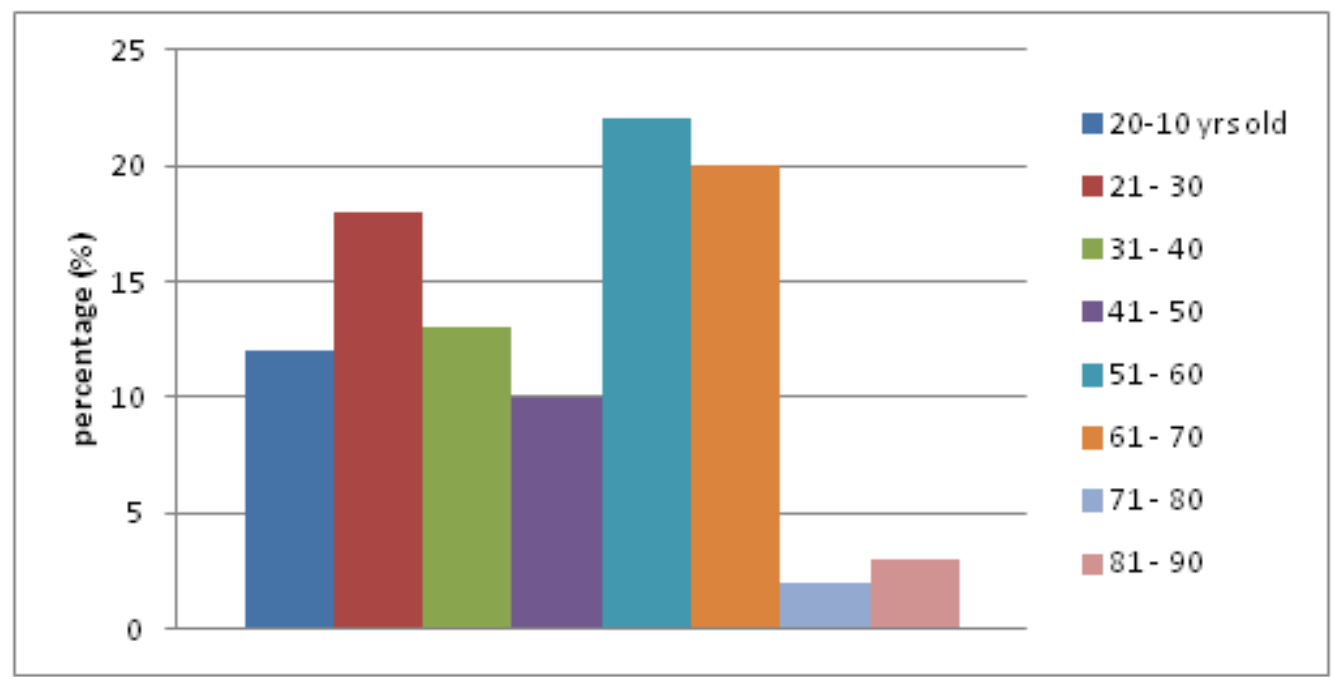

Diagram 2. Percentages of age distribution for 60 respondents

(2007). Please refer Figure 1 for distribution map of Dusun language speakers.Although the majority of population in Mukim Ukong is Dusun ethnic group, other ethnic minorities are also present. These ethnics are believed to be mutually adapted to intercultural communication among each other on a daily basis. Each of these demographics is believed to have different perspective on their language used. Hypothetically, these populations are expected to employ their native tongues, but at once, without constraint to use any particular codes.

\section{RESULTS AND DISCUSSION}

Results of the 60 distributed questionnaires show that in terms of ethnicity background, the respondents consist of: 35 out of 60 respondents are those of minority Dusun;

Table 1. The code choice among Dusun speakers within intercultural communication with other ethnicities

\begin{tabular}{lr}
\hline Number of respondents employ Dusun code & 16 out of 35 (46\%) \\
Number of respondents employ Brunei Malay code & 9 out of 35 (26\%) \\
Number of respondents employ code mixing of both Dusun and Brunei Malay & 10 out of 35 (28\%) \\
\hline
\end{tabular}

20 of Bruneian-Malay, and the other five are Kedayan Malay. Both Diagram 1 and 2 show the ethnicity percentage of respondents and respondents' age distribution respectively.Early research analyses suggest that the code choice of the current study is motivated by certain needs, situations and setting. The code choice itself is correlated with certain social variables, which predominantly show the ethnic differences and age, as well as the academic status of the speakers. In terms of ethnic differences, $100 \%$ of respondents from both Bruneian Malay and Kedayan Malay are more comfortable to employ Brunei Malay when they communicate with other ethnics. Meanwhile, the selection of code in intercultural communication amongst Dusun ethnic minority is more varied. This can be seen from Table 1 below:

Multilingual phenomenon can be found as a few numbers of Dusun speakers still retain their native language of Dusun when they converse with other ethnics, the Brunei Malay or Kedayan Malay in particular. Their language competency to speak and understand these other languages can be ascertained from their statements. Among the reasons (taken from the distributed surveys) why they prefer Dusun over the other codes are: "Lebih mudah" [ET: It is practically easier] (Male senior citizen, 62 years old); "Jika mereka tahu bahasa Dusun dan pandai bahasa Dusun, tidak perlu cakap Melayu" [ET: If they know Dusun, we don't have to speak in Malay] (Male, 56 years); and "Jumpa Melayu atau bangsa India yang faham cakap Dusun, cakap Dusun saja kerana tidak guna bercakap Melayu" [ET: If you meet those people of the Malays or Indians who understand Dusun, there is no need to speak in Malay] (Female, 52 years). These statements have indicated some Dusun ethnic groups will remain employing their native tongue even in intercultural communication, as they expect their audiences will understand the Dusun.

On the other hand, it is also found that some Dusun natives have the tendency to employ code mixing of Dusun and Malay, or even conversing with Brunei Malay code completely. Based on the statements given, they claim that their communication will be easier by using Brunei Malay, as it is more 'universal' than any other languages: "Bertutur dalam bahasa Melayu memudahkan komunikasi dan pemahaman" [ET: To speak in Malay language would make communication and understanding easier] (Female, 24 years old): "Lebih kepada bahasa Melayu kerana orang lebih faham bahasa Melayu" [ET: I use Malay language as other would understand it better] (Male senior citizen, 61 years old). Similar reason was given by all of the respondents from Bruneian Malays and Kedayan Malays, who also choose 
Brunei Malay in their daily communication. This supports a remark by Gunn (1997) who stated Brunei Malay is the 'lingua franca' to the majority of Bruneians. This finding deliberately clarifies that any of these speakers, despite coming from different ethnicities, are free to pick a specific communication code based on their need and motivation. As the current study involves multilingual setting and intercultural communication, relatively complex sociolinguistic phenomena can be found when these native speakers are not necessarily practising their native code in their daily lives, but tend to assimilate the 'universal' Brunei Malay. This has been emphasised previously by Chuchu (2009) who stated Brunei Malay as a daily communication code is undeniably used extensively by the people of Brunei, whether in intercultural communication or even in more formal situations.

The researchers also found the existence of multilingual communication among these speakers in natural setting. Both Appendix 1 and Appendix 2 show two examples of communication episode obtained with unique intercultural phenomenon. Both communication episodes show the basis of intercultural communication. It is clear that there is mutual understanding between speakers, even when they employ different codes within an episode of conversation. Their understanding towards each other indicates that they do not have to explain every utterance that is shared. Apart from previous statements, the current study also found that there are several motivations causing the Dusun speakers to maintain their native tongue. Several interviewed informants claimed the importance of the mother tongue as a representation of their ethnic root that they will never eradicate. The following shows several statements given by these informants:

(1) "Dusun atu penting, mana inda penting atu asalmu. Awu eh, kira asal-usulmu, inda dapat $\begin{array}{llllllll}d & i & b & u & a & n & g\end{array}$ $<$ Awg Mokti; 83; UKO13-MN-8; 4:55>

[ET: Dusun is important for us as it represents our root. Yes, it cannot be separated from us].

(2) "Mestilah penting, kitani mana boleh membuang bahasa kitani sendiri. Even kitani ada biasa cakap Melayu everyday kan, indakan kitani buang bahasa kitani, karang ilang tia. Siapakan lagi kalau kitani nada"

$<$ Dyg Kamisah; 53; UKO13-MN-10; 4:09>

[ET: Dusun language is indeed crucial. We cannot get rid of our own language, even if it is now become habitual among us to speak in Malay. It is impossible

Diagram 3. Code choice among Dusun natives to their younger audience

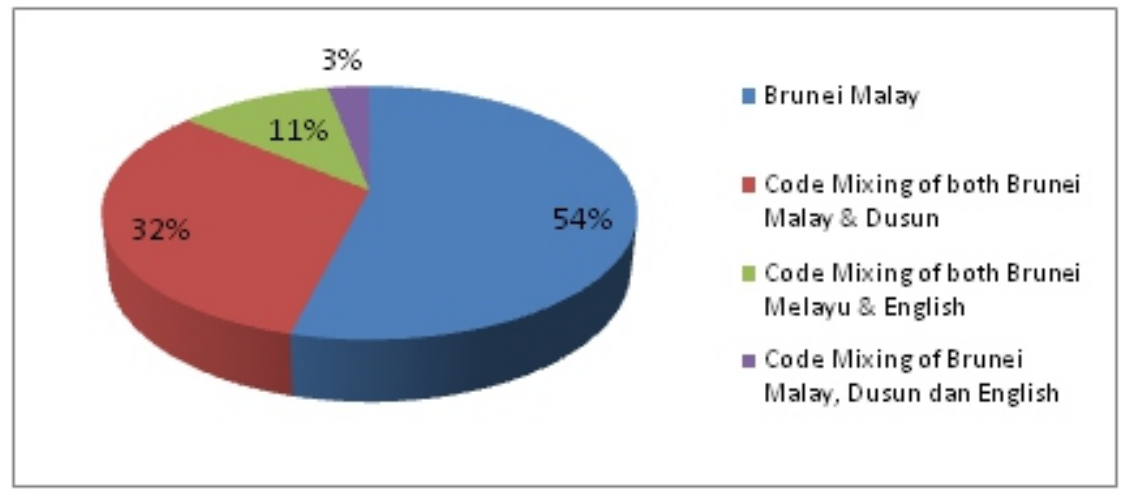

for us to get rid of our own language, it will extinct if that was the case. If we do not practise it, who else would?].

Another interesting phenomenon found is on how the social variable of age could also influence the code choice among speakers towards their counter-speakers or speech audience. While Bruneian Malays remain to use Brunei Malay on a regular basis, only one out of 10 respondents from Kedayan Malay (Female, 45) stated that she would change her code to Kedayan Malay when conversing with the elders from the same race as a means of showing 'respect'. Meanwhile, among the speakers of Dusun, their audience age plays an important role in the selection of a particular code. A total of 21 out of 35 respondents $(60 \%)$ prefer Dusun when conversing with their elders; of their mother, father, or grandmothers. The rest are quite likely to employ Brunei Malay. However, none of them employ Dusun to younger audience, such as their children, grandchildren, or younger relatives. Younger speakers on the other hand, tend to use Brunei Malay or code mixing of both. Summary of the codechoice based on the respondents' younger audience can be seen in Diagram 3. Aside from the hegemony of local vernacular of Brunei Malay, which has obvious impact on Bruneians' daily communication, adjustment of code towards their audience also happened due to several reasons. This is reflected in the statements by these informants:

(3) "Anak-anak baru mesti kami cakap Melayu. Durang faham tapi durang membunyikan percakapan atu inda lurus, inda ngam, macam karau bunyinya, percakapan inda tepat, iatah pakai 
Me l a y u

$<$ Awg Tawar; 60; UKO13-MN-8; 9:03>

$s$ a $j$ a"

[ET: We have to employ Malay when speaking to the younger generations. They understand Dusun, but there are problems if they want to converse with it. They could not speak Dusun very well and the accent is not correct. Therefore, I'd rather use Malay language instead].

(4) “...Dusun aku inda berapa, inda pandai membalas. Faham tapi inda pandai membalas. Pakai Melayu saja"

$<$ Dyg Nurul; 19; UKO13-MN-9; 2:05>

[ET: My proficiency in Dusun is not good. I do not know how to reply them in Dusun. I understand them, but cannot converse with it. Therefore, I use Malay language only].

(5)“Anak-anak masa ani cakap Melayu saja tapi durang merati pulang tapi aku bercakap ani cakap Dusun pulang tapi durang merati jua tapi balasnya cakap Melayu, awu awu cakap Dusun atu ia tau $\begin{array}{lcc}b & a & h \\ <\text { Awg Mokti; 83; UKO13-MN-8; 1:54> }\end{array}$

[ET: Nowadays, younger generations can only speak Malay, even though they do understand the Dusun. I personally speak in Dusun with them, as they would understand. But, they will definitely reply in Malay. Yes, indeed, they understand Dusun].

The above statements show switching of codes within Dusun ethnic groups is indeed practised intentionally. Seng (2000) has stated such phenomenon is normally intended whether to 'remove' or 'include' a person in their conversation. As proposed by Bell (1997) through his 1984's Audience Design, the shifting of styles, or particularly in the current study, the changes of code from the usual Dusun to Brunei Malay to converse with the younger audiences are believed to have its own responsive social meanings. The motivation to switch between codes among Dusun ethnic groups is merely to facilitate communication between speakers, and to maximise understanding between them, as the Dusun language competency among the younger native Dusuns is relatively low. Thus, they prefer to practise the Malay that is mutually understood. This also shows that solidarity among generations of Dusun is being practised through their medium of communication. Even though the occurrence of such code choice happened within the Dusun ethnic groups only and did not involve intercultural elements, the current study still considers this finding as a unique sociolinguistic phenomenon, as it involves the use of several codes of Dusun, Brunei Malay and English, which are intelligible to each other. Nevertheless, there is no element of inconvenience among these speakers to comprehend each other. This was clearly stated by several informants:

(6) “...kalau ia cakap Melayu aku balas cakap Dusun tetapi fahamlah, jadi kebiasaan sudah. Inda rasa payah, pasal biasa sudah jua"

$<$ Dyg Kamisah; 53; UKO13-

$\mathrm{MN}-10 ; 3: 39>$

[ET: If they speak in Malay, I will reply in Dusun. I can still understand them as it is habitual to me. I don't get any complication as I am used to it].

(7) “...tiada menjadi masalah tu, apa jua, mun sudah jadi kebiasaan, durang tau jua tu cakap Dusun, fah a m jua" $<$ Dyg Sunik; 52; UKO13-MN-11; 3:37>

[ET: It is not a problem at all, as it has become habitual for us. They can understand the Dusun as

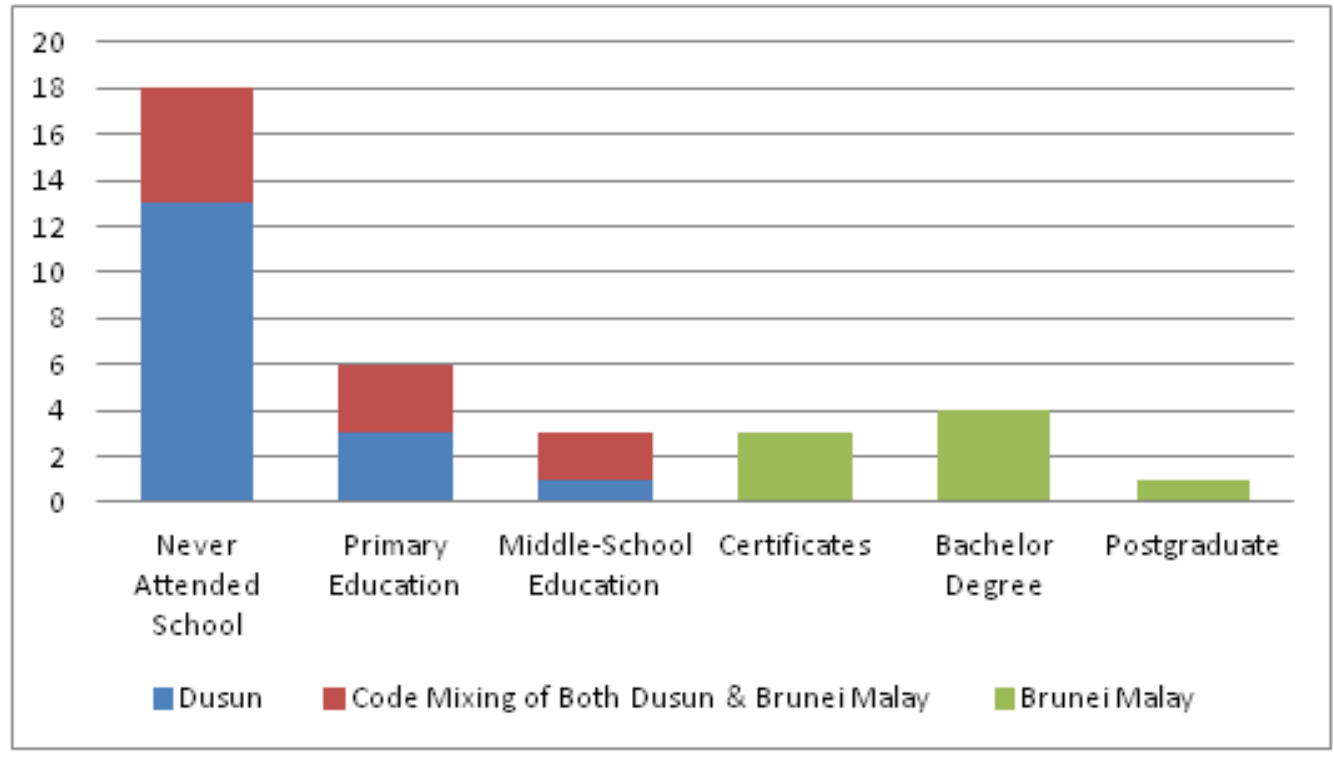

Diagram 4. Number of Dusuns and their code-choices based on their academic statuses 
well]

(8) “...Awu, inda payah kan faham, nada masalah jua bah, selalu jua sudah mendangar atu jua, cana kan cakap ah tapi memang sudah fahamlah"

$<$ Dyg Hazney; 25; UKO13-MN-12; 2.58>

[ET: Yes, it is not difficult for me to understand. It was never a problem. This is because we get used to it. I do not know how to explain it thoroughly, but we do understand them]

Following earlier findings, further analyses were performed on the ethnic differences and code choice, while correlating these to the academic status of speakers. Social variable of academic status is also believed to have its certain influences and motivations on the code choice within intercultural communication among these speakers. The current study has categorised the academic status into groups of: Never Attended School; Primary Education; Middle-School Education; Certificates; Bachelor Degree; and Postgraduate level-based on analyses of distributed questionnaires. As expected, different levels of academic status among Bruneian Malays and Kedayan Malays do not affect their preferences towards the imperative Brunei Malay. However, this is rather varied among the Dusuns, as stratification of academic statuses shows a trend towards their code choices in intercultural communication. This can be seen from the following Diagram 4.

These findings show those who have never attended any school during their younger years (these people are those of the age of $40 \mathrm{~s}$ and over, who were working as a blue collar workers during their younger age, or worked independently as farmers, rubber tappers or in termite control) are more likely to maintain choosing the native code of Dusun in intercultural communication. The researchers believe that this happened as these speakers have less exposure to education. Thus, they are more 'integrated' to their familiar spoken code - Dusun. As previously claimed by informants, these speakers also see themselves as those who have the need to protect and practise their culture and heritage. However, this is contrary to those who are exposed to educations, particularly those with Degrees. These speakers have a tendency to choose Brunei Malay in any intercultural communication. As bilingualism of both Malay and English language has been widely practised through education system in Brunei since 1984 to date, this is also believed to be one of the grounds of their predilection towards conversing in Malay (or Brunei Malay), and even English on a regular basis. These preferences can be distinguished from a few of these informants' statements as of the following:

(9) "Aa, kebiasaan sudah jua kan cakap Melayu jadinya gunakan saja cakap Melayu lah, lebih mudah untuk berkomunikasi jua bah, orang pun paham"

UKO13-MN-14; 0:27>

$<$ Dyg $\mathrm{Nie} ; 34$

[ET: I get used to speak in Malay. Therefore, I adopt Malay better. It would be easier for me to communicate as others would understand it better].

(10) "Kalau for me, I prefer to speak in Malay saja, I mean, I've been exposed to Malay since I was a kid, walau ada kadang-kadangnya my mum speaks Dusun with me but I'd rather speak Malay. My Dusun sounds very weird"

$<$ Dyg Katie; 28; UKO13-MN-15; 1:21>

[ET: I prefer to speak in Malay. I mean, I have been exposed to Malay language since I was a kid, even though there are times my Mum would speak Dusun to me. But, I'd rather speak Malay. My Dusun sounds very weird].

The hegemony of Standard Malay, Brunei Malay or even the English language over the ethnic codes among the younger generations of Brunei today is perhaps undisputable as a result of their exposures to the education policy in Brunei. This has been suggested by Jones (1996) and Gunn (1997) who conveyed that the bilingualism education policy implemented by Brunei since the earliest years of formal education has positioned the Malay as the official language, whilst putting heavy emphasis on the English language. This is later stretched by the latest implementation of the Brunei Darussalam's National Education System for the 21 st Century, also known as 'Sistem Pendidikan Negara Abad ke-21' (the 21st Century National Education System). The declining number of native speakers among younger generations of Bruneian has also been suggested by the study of Othman (2007), as he stated the transmission of ethnic dialects among contemporary families in Brunei has changed overtime. As the generation passes by, they are inclined to speak with either local vernacular Malay or English code and practise less ethnic dialects-predominantly due to immense exposures of formal education and globalisation. Furthermore, Brunei has yet to implement mass mother-tongue based education or subjects for its indigenous people (David, Cavallaro \& Coluzzi, 2009; Coluzzi, 2013); hence, the decreasing number of native speakers and causing these ethnic minority languages and dialects to be prone to be endangerment.

As previously stated, even though these ethnic speakers are dealing in intercultural communication or practising intelligible codes in particular, it is found that there is no greater complication or confusion among the speakers. Based on the survey findings, $100 \%$ of the respondents have stated that there was only little to no complexity to understand each other when communicating with a variety of codes at once-as this is habitual to them. Further analyses were done with two informants from Bruneian Malay and Kedayan Malay who currently reside with their extended families (on the basis of marriage) that employ Dusun code. Both of them have stated that they did not experience greater problem to comprehend the Dusun and converse in the code of their choice-the Brunei Malay. 
(11) "Tiada masalah kan fahamlah, kalau ada kesukaran atu jua, kira aku bertanya saja, nada masalah"

$<$ Dyg Sarinah; 45; Kedayan Malay; UKO13-MN$5 ; 1: 34>$

[ET: It is not a problem to understand them. If there are any difficulties, I would ask. There is no greater problem at all].

(12) "Faham cakap durang, kalau inda faham apa erti-ertinya tanya saja apa ertinya. Kalau dikatakan sukar inda jua, tapi okey lah, pasal dalam perkataan durang atu mesti ada yang ku fahamlah" $<$ Awg Jaafar; 61; Bruneian Malay; UKO13-MN-6; $3: 40>$

[ET: I do understand their conversation. If I do not, I will ask. I would not say that it is troublesome because everything is fine for me so far. This is because I understand their speech well enough].

\section{CONCLUSION}

As Brunei is a country with multilingual settings, it has generated diverse features of unique linguistics and sociolinguistic phenomena; for instance, the occurrences of cross-cultural elements related to the languages or dialects of ethnic minorities. Current undertaken research has focused upon intercultural communication among Brunei minority ethnic groups in Mukim Ukong, Tutong, which have shown different strains of code choices: among an ethnic group to another; from the older generation to their younger audience; and based on their academic statuses. To date, the mutual understanding these ethnics have of each other has not caused any complications towards their communication, even when they are using different intelligible codes in the same communication episode.

From current findings, the research has indicated that, even though multilingualism deals with complex phenomena, it also shows that each speaker is unbound to choose specific code when they are communicating with specific audience and at a certain event. The selection of these codes occurs in accordance with their needs and motivations. Despite an intercultural communication involving intelligible codes, understanding and harmony between users still exist. To some extent, this current investigation has also implicated and suggested other areas of research that could be done in the future; for instance, investigating the vitality or revitalisation of these ethnic groups' languages and dialects that ought to be undertaken.

\section{REFERENCES}

Alas, Y. (1995). Pinjaman atau asli?Satu kajian linguistik perbandingan dalam bahasa Dusun. Janang, September, 5, pp. 82-94.

Alas, Y. (2009). Tanah leluhur masyarakat Dusun: Perspektif linguistik. South East Asia: A Multidisciplinary Journal, 9, pp. 107-121.
Bell, A. (1997). "Language style as audience design" in N. Coupland \& A. Jaworski (Eds.) Sociolinguistics (pp. 240-250) New York: Palgrave.

Chuchu, F. (2009). Bahasa Dalam and Malay speech etiquette in Brunei Darussalam, Bandar Seri Begawan: Dewan Bahasa dan Pustaka.

Chuchu, F.\& Poedjosoedarmo, S. (1995). Triglossia among the people of Brunei. Purih: Sempena sepuluh tahun penubuhan UBD, Tungku Link, Universiti Brunei Darussalam, pp: 93-100.

Coluzzi, P. (2013). Language planning for the minority language in Brunei. Conference proceeding of kepelbagaian bahasa di Borneo: Bahasa sebagai mozaik sosial ekonomi dan budaya. Bandar Seri Begawan: Dewan Bahasa dan Pustaka.

David, M.K., Cavallaro, F. \& Coluzzi, P. (2009). Language policies - Impact on language maintenance and teaching: Focus on Malaysia, Singapore, Brunei and The Phillipines. in F. Cavallaro, A. Milde \& P.Sercombe (Eds.), The Linguistic Journals, pp. 155-191.

Fishman, J. (1972). Domains and the relationship between micro-and macrosociolinguistics in John J. Gumperz \& Dell Hymes (Eds.) Directions in sociolinguistics: The ethnography of communication, (pp. 435-453), New York, Holt, Rinehart and Winston.

Fok, C.A. (2008). Pronomin persona Bahasa Dusun. Dialek peribumi warisan ketrampilan jati diriConference proceeding, in Seminar Antarabangsa Dialek-Dialek Austronesia di Nusantara III 16-18 Muharam 1429/24-26 January, pp. 199-216.

Gal, S. (2007). Multiligualism in C.Llamas, L.Mullany \& P. Stockwell (Eds.).The Routledge companion to sociolinguistics, Oxon: Routledge.

Goebel, Z. (2002). Code choice in inter-ethnic interactions in two urban neighbourhoods of Indonesia, International Journal of the Sociology of Language, 158, pp.69-87.

Gumperz, J.J. (1982). Interethnic communication in J.J. Gumperz (Ed.) Discourse strategies, Cambridge: Cambridge University Press, pp. 172-86.

Gunn, G. C. (1997). Language, power, \& ideology in Brunei Darussalam. Ohio: Ohio University Press.

Halus, D.R.P. (2009). Pengimbuhan dan fungsi kata kerja dan kata nama dalam Bahasa Dusun Merangking, Mukim Bukit Sawat. Bandar Seri Begawan: Dewan Bahasa dan Pustaka.

Jandt, F. E. (1998). Intercultural communication: An introduction. Michigan: Sage Publication.

Jones, G. M. (1996)/ The bilingual education policy in Brunei Darussalam in P. W. Martin, C. Ozog \& G. Poedjosoedarmo (Eds.), Language use \& language change in Brunei Darussalam (pp. 123132). Ohio: Ohio University Center for International Studies Monographs in International Studies.

Karim, A. (2005), Kontak budaya dan kesannya: Pemindahan leksikal. Jurnal Bahasa, Bil. 8, July- 
Dec, Bandar Seri Begawan: Dewan Bahasa dan Pustaka, pp. 46-59.

Karim, A. (2007). Preposisi bahasa Dusun dan bahasa Melayu: Satu analisis kontrastif dan analisis kesilapan. Bandar Seri Begawan: Dewan Bahasa dan Pustaka.

Karim, A. (2008). Pembentukan kata kerja bahasa dusun di negara Brunei Darussalam. Conference paper presented at Seminar Antarabangsa DialekDialek Austronesia Di Nusantara III. Dewan Canselor, Universiti Brunei Darussalam, 16-18 Muharam 1429/24-26 January.

Othman, A. (2007), Multibahasa: Dinamisme baru generasi ketiga dalam persekitaran dunia yang berubah. Conference paper presented at Seminar Tahunan Bahasa Melayu dan Linguistik, Kali ke2 (SETALING II), Fakulti Sastera dan Sains Sosial, Univeristi Brunei Darussalam, January, 24-25.

Seng, T.K. (2000). Sosiolinguistik. Bangi: Pusat
Pengajian Jarak Jauh, Universiti Kebangsaan Malaysia.

Shaleh, I.M. (2010). Komuniti Iban dan Melayu di Badau: Satu tinjauan dari aspek bilingualisme/. Jurnal Bahasa, Bil. 20, May-August, Bandar Seri Begawan,: Dewan Bahasa dan Pustaka, pp. 1-11. Swann, J, Mesthrie, R., Deumert, A.,\& Lillis, T.M. (2004). A Dictionary of sociolinguistics. Edinburgh: Edinburgh University Press.

The Government of Brunei, (1961). Undang-undang taraf kebangsaan undang-undang No. 4 Suratsurat Perlembagaan Negeri, Bandar Seri Begawan, Government Printer, pp. 115-132.

Trudgill, P. (2003). A glossary of sociolinguistics. Oxford: Oxford University Press.

Tsuda, Y. (1986). Democratization of language choice in intercultural communication. Naosite: Nagasaki University's Academic Output SITE, pp. 69-82. 